\title{
Leaf and Root Growth, Carbon and Nitrogen Contents, and Gene Expression of Perennial Ryegrass to Different Nitrogen Supplies
}

\author{
Yiwei Jiang ${ }^{1}$ \\ College of Agronomy, Resources and Environment, Tianjin Agricultural University, Tianjin, 300384, \\ PR China; and Department of Agronomy, Purdue University, West Lafayette, IN 47907 \\ Yaoshen Li \\ College of Agronomy, Shanxi Agricultural University, Taigu, Shanxi Province, 030801, PR China \\ Gang Nie \\ Department of Grassland Science, Sichuan Agricultural University, Chengdu, Sichuan Province, \\ 611130, PR China \\ Huifen Liu \\ College of Agronomy, Resources and Environment, Tianjin Agricultural University, Tianjin, 300384, \\ PR China
}

\begin{abstract}
AdDITIONAL INDEX wORDs. carbon to nitrogen ratio, glutamine synthetase, Lolium perenne, metabolism, nitrate reductase, nitrogen use efficiency

Abstract. Nitrogen greatly impacts plant growth and development. The objective of this study was to characterize growth, nitrogen use, and gene expression of perennial ryegrass (Lolium perenne) in response to increasing nitrogen supplies. Perennial ryegrass (cv. Inspire) was grown in sand culture and irrigated with a half-Hoagland solution amended with $0,0.5,1.0,2.5,5.0$, and $7.5 \mathrm{~mm}$ nitrogen. Leaf tissues were harvested at 10 days (first cutting) and 20 days (second cutting) and roots were harvested at 20 days. The relatively higher $\mathrm{N}$ supply (2.0-7.5 mu) resulted in a larger amount of leaf fresh and dry weight but lower root fresh and dry weight, especially for the second cutting. Root:leaf ratio was higher under low $\mathrm{N}$, but lower under the high $\mathrm{N}$ treatment. Leaf $\mathrm{N}$ content was relatively higher under $2.5,5$, and $7.5 \mathrm{~mm} \mathrm{~N}$ than under the other three treatments, while $2.5 \mathrm{~mm} \mathrm{~N}$ exhibited relatively higher leaf carbon content for both cuttings. Leaf $C: N$ ratio and leaf nitrogen use efficiency (LNUE) decreased with increasing $N$ supplies for the first cutting but were higher under low $N(0-1.0 \mathrm{mM})$ for both cuttings. Leaf $\mathrm{C}: \mathrm{N}$ ratio and LNUE did not differ among low $N$ and LNUE also remained unchanged among high $N$ for the second cutting. Root $N$ content increased, but the root $\mathrm{C}: \mathrm{N}$ ratio and root $\mathrm{N}$ use efficiency (RNUE) decreased with increasing $\mathrm{N}$ supplies, especially under $2.5,5.0$, and $7.5 \mathrm{~mm}$ N. Low $(0.5 \mathrm{~mm})$, moderate $(2.5 \mathrm{~mm})$, and high $(7.5 \mathrm{~mm}) \mathrm{N}$ were chosen to examine the expression level of $N R$ encoding nitrate reductase and GS1b encoding glutamine synthetase. Treatment of $0.5 \mathrm{~mm} \mathrm{~N}$ had higher expression levels of leaf $N R$ than other two treatments for both cuttings and a higher level of leaf $G S$ for the second cutting. Expression of $N R$ in the roots did not vary among treatments but the expression of $G S$ increased under 2.5 and 7.5 mM, compared with the $0.5 \mathrm{~mm}$ N. Differential leaf and root growth and physiological responses to low $\mathrm{N}(0$ to $1 \mathrm{~mm})$ and to moderate to high $\mathrm{N}$ (2.5 to $7.5 \mathrm{~mm}$ ) could be used for examining the natural variation of $\mathrm{N}$ use in diverse perennial ryegrass populations.
\end{abstract}

Nitrogen management is an important cultural practice for perennial grass production. An insufficient $\mathrm{N}$ supply can weaken plants, but excessive applications of $\mathrm{N}$ may also lead to problems of plant health and vigor. The extensive use of $\mathrm{N}$ fertilizers is one of the major factors that may contribute to cost increases in perennial grass management. Plants use only a certain amount of $\mathrm{N}$; extra $\mathrm{N}$ not used by plants can be lost via leakage into the atmosphere, groundwater, lakes, and rivers, which pollutes soil and water (Masclaux-Daubresse et al., 2010). It has been estimated that $50 \%$ to $70 \%$ of the $\mathrm{N}$ provided to the soil is lost (Good et al., 2004). Therefore, the possibility of lowering fertilizer input and developing new cultivars with improved N use efficiency (NUE) is desirable for optimizing perennial grass management and production.

Received for publication 18 July 2016. Accepted for publication 2 Sept. 2016. ${ }^{1}$ Corresponding author. E-mail: yjiang@purdue.edu.
Nitrogen is directly correlated with increased plant biomass production (Sinclair and Vadez, 2002). Efficient use of $\mathrm{N}$ has been associated with nitrogen uptake efficiency and NUE. Nitrogen uptake is strongly influenced by the roots, and larger root systems may facilitate $\mathrm{N}$ uptake, especially under N-limiting environments. Both shoot and root weight of several cool-season grass species were reduced under low-N conditions, but to a lesser extent in roots, resulting in an increase in the root:shoot ratio in plant species (Skinner and Comas, 2010). For warm-season grasses, st. augustinegrass (Stenotaphrum secundatum) had greater $\mathrm{N}$ partitioning to roots than bermudagrass (Cynodon dactylon), bahiagrass (Paspalum notatum), and zoysiagrass (Zoysia japonica) based on root length, root:shoot ratio, and $\mathrm{N}$ content in roots, suggesting that st. augustinegrass has a potential for improved $\mathrm{N}$ retention in roots (Poudel et al., 2013). In finger millet (Eleusine coracana), declines in shoot and root growth under low $\mathrm{N}$ were associated with decreased shoot tiller number, crown root number, total crown root length, 
and total lateral root length, but with no consistent changes in root hair traits (Goron et al., 2015). The results demonstrate that lower reductions in root growth and related morphological changes are important traits for adaptation of plants to a low-N environment.

Previous reports showed that species and cultivars vary greatly in growth and NUE in response to $\mathrm{N}$ supply. For example, kentucky bluegrass (Poa pratensis) cultivars differed in NUE (Jiang et al., 2000), and N recovery in clippings was greater for kentucky bluegrass than perennial ryegrass and tall fescue (Lolium arundinaceum) (Liu and Hull, 2006). Nitrate uptake was positively correlated with NUE in creeping bentgrass (Agrostis stolonifera) but not in perennial ryegrass (Bushoven and Hull, 2001). NUE of barley (Hordeum vulgare) genotypes varying in $\mathrm{N}$ response was higher under low $\mathrm{N}$ resupply than under normal $\mathrm{N}$ resupply after $\mathrm{N}$ deprivation $(\mathrm{Xu}$ et al., 2016). Collectively, the ability of perennial grass plants to use $\mathrm{N}$ depends on the soil type, the environment, and the plant species (Arrobas et al., 2011; Jiang et al., 2000; Liu and Hull 2006; Mattsson and Schjoerring 2002; Moir et al., 2012). Characterization of plant growth responses to variable $\mathrm{N}$ conditions and $\mathrm{N}$ partitioning mechanisms across different species, cultivars, or tissues can provide a basis for a better understanding of $\mathrm{N}$ utilization.

At the cellular and molecular levels, the capacity of $\mathrm{N}$ metabolism also influences efficient use of $\mathrm{N}$. It is known that $\mathrm{N}$ assimilation involves the reduction of nitrate to nitrite and then to ammonium catalyzed by nitrate reductase (NR) and nitrite reductase (Meyer and Stitt, 2001), and ammonium produced by this process is then converted into organic molecules by the glutamine synthetase (GS)/glutamate synthase pathway (Hirel and Lea, 2001). The higher enzyme activities and expression of genes encoding these enzymes may contribute to $\mathrm{N}$ assimilation, especially under low-N conditions. For example, $\mathrm{N}$ deficiency increased GS activities in both young and old leaves and roots of creeping bentgrass at 14, 21, and 28 d of treatment (Jiang et al., 2011). The higher NR and GS activities in roots of barley genotypes with low or high NUE were also found under low N supply, and changes in enzyme activities were consistent with upregulated gene expression of $H v N R 1, H v G S 1-1$, and $H v G S 1-2$ (Xu et al., 2016). Similarly, low N supply from sodium nitrate and potassium nitrate resulted in a significant increase in the nitrate/nitrite mRNA production in wheat (Tritium aestivum), whereas high concentrations suppressed the expression of $N R$ (Kavoosi et al., 2014). Furthermore, overexpression of a tobacco (Nicotiana tabacum) NR gene in wheat improved NUE and increased seed protein content and weight without augmenting $\mathrm{N}$ supply (Zhao et al., 2013). The results suggested a positive role of $N R$ in $\mathrm{N}$ metabolism. In addition, overexpression of cytosolic $G S$ in rice (Oryza sativa) significantly improved the nitrogen harvest index (Brauer et al., 2011), demonstrating that $\mathrm{N}$ partitioning in rice during grain filling could be altered by $G S 1$. However, overexpressing $O_{s} G S 1 ; 1$ and $O_{s} G S 1 ; 2$ resulted in poor plant growth, yield and decreased $\mathrm{C}: \mathrm{N}$ ratio in the stem of rice, indicating roles of these two genes in $\mathrm{N}$ metabolism, particularly under sufficient $\mathrm{N}$ conditions (Bao et al., 2014). The results suggest a complex role of $G S$ genes in regulating nitrogen metabolism, depending on plant species and $\mathrm{N}$ availability.

Perennial ryegrass is a widely used cool-season forage and turf species. However, this species has shallow roots, with up to
$80 \%$ of its roots in the top $15 \mathrm{~cm}$ of soil (Haynes and Williams, 1993). The limited root system may influence $N$ uptake and utilization, especially under N-limiting conditions. Although nitrogen use and metabolic changes in response to low or high $\mathrm{N}$ have been reported in perennial ryegrass (Foito et al., 2013; Liu and Hull, 2006; Rasmussen et al., 2008; Roche et al., 2016), leaf and root growth, $\mathrm{N}$ partitioning, and molecular responses of this species to a range of $\mathrm{N}$ supplies are not well understood. In particular, how $\mathrm{N}$ supply impacts regrowth and $\mathrm{N}$ use after foliage removal (clipping) is largely unknown. Therefore, the experiment was designed to characterize plant growth, carbon content, NUE as well as expression of key genes involved in N metabolism in response to increasing $\mathrm{N}$ supplies. The results from the study would reveal whole-plant and cellular mechanisms of $\mathrm{N}$ metabolism in perennial ryegrass.

\section{Materials and Methods}

Plant materials and growth conditions. The perennial ryegrass cultivar Inspire was used in the experiment. The seeds were sown in plastic pots $(10 \mathrm{~cm}$ diameter, $9 \mathrm{~cm}$ deep) containing sand in a greenhouse at Purdue University, West Lafayette, IN. Plants were watered twice per week with a halfstrength Hoagland solution (Hoagland and Arnon, 1950) at a $\mathrm{pH}$ of 6.5 and an electrical conductivity (EC) of $1.15 \mathrm{dS} \cdot \mathrm{m}^{-1}$. Plants were cut once a week to $2-3 \mathrm{~cm}$. During the growing and treatment periods, the average air temperature was $19 \pm 1.5^{\circ} \mathrm{C}$ and photosynthetic photon flux density was $\approx 400 \mu \mathrm{mol} \cdot \mathrm{m}^{-2} \cdot \mathrm{s}^{-1}$, with a 10-h light period of natural and artificial light.

N TREATMENT. Before initiation of the $\mathrm{N}$ treatments, each pot was irrigated multiple times with deionized water to minimize $\mathrm{N}$ in the sand. Also before $\mathrm{N}$ treatments, all plants were cut to a height of 2-3 cm so that later measurements would be made on tissue produced after the imposition of $\mathrm{N}$ treatment. Beginning 29 Jan. 2016, plants were irrigated daily with a $50 \mathrm{~mL}$ half-Hoagland solution amended with $0,0.5,1.0$, $2.5,5.0$, and $7.5 \mathrm{~mm} \mathrm{~N}$. The $50 \mathrm{~mL}$ of solution provided sufficient irrigation for each pot and allowed free drainage to occur to each pot. $\mathrm{KNO}_{3}$ and $\mathrm{Ca}\left(\mathrm{NO}_{3}\right)_{2}$ were used as the nitrate sources in the solution. Nitrate level in the Hoagland solution was adjusted to each targeted $\mathrm{N}$ level. Potassium and calcium levels were equalized across treatments by adding $\mathrm{KCl}$ and $\mathrm{CaCl}_{2}$ into the lower $\mathrm{N}$ treatment solution. $\mathrm{pH}$ and $\mathrm{EC}$ values were kept the same as described above.

Measurements. Plant height (HT) was measured every $2 \mathrm{~d}$ from the soil surface to the top of the uppermost leaf blade. Plants were cut after the treatments were imposed. Specifically, after $10 \mathrm{~d}$ of $\mathrm{N}$ treatment, grasses were cut to $2-3 \mathrm{~cm}$ (the first cutting) and leaves were harvested for determining content of chlorophyll (Chl) and carotenoid (Car), leaf fresh weight (LFW), leaf dry weight (LDW), leaf $\mathrm{N}$ and $\mathrm{C}$ contents, and gene expression. At the end of the treatment $(20 \mathrm{~d})$, leaves were cut again to $2-3 \mathrm{~cm}$ (the second cutting) to repeat the various measurements mentioned above. At $21 \mathrm{~d}$, roots were harvested for determining root fresh weight (RFW), root dry weight (RDW), $\mathrm{N}$ and $\mathrm{C}$ contents, and gene expression.

Leaf $\mathrm{Chl}$ and Car were extracted by soaking $\approx 90 \mathrm{mg}$ leaf samples in $15 \mathrm{~mL}$ dimethyl sulfoxide (DMSO) in the dark for $48 \mathrm{~h}$. The absorbance was then read at 665, 649, and $480 \mathrm{~nm}$ and $\mathrm{Chl}$ and Car contents were calculated using the method of Wellburn (1994). LDW and RDW were measured after drying at $80{ }^{\circ} \mathrm{C}$ in an oven for $3 \mathrm{~d}$. The root:leaf ratio was calculated as 
RDW/LDW. About $10 \mathrm{mg}$ of ground leaves and $30 \mathrm{mg}$ of ground root samples were analyzed in a dry combustion analyzer (CHN 2000; Leco Corp., St. Joseph, MI) equipped with infrared cell and thermal conductivity detectors for $\mathrm{C}$ and $\mathrm{N}$ concentrations, respectively. NUE was defined as grams of dry matter per gram $\mathrm{N}$ present in the tissue using clippings (Jiang et al., 2000), and was calculated as follow: LNUE = $\mathrm{LDW} /$ leaf $\mathrm{N}$ content; RNUE $=\mathrm{RDW} /$ root $\mathrm{N}$ content. The $\mathrm{C}: \mathrm{N}$ ratio was calculated as leaf (or root) $\mathrm{C}$ content/leaf (or root) $\mathrm{N}$ content.

Real-time quantitative reverse transcription polymerase chain reaction (qRT-PCR) was conducted to examine gene expression in leaf and root samples under low (0.5 mM), moderate $(2.5 \mathrm{~mm})$, and high $(7.5 \mathrm{~mm}) \mathrm{N}$ treatments. Briefly, total RNA was isolated using a Direct-zol ${ }^{\text {TM }}$ RNA MiniPrep Kit (Zymo Research Corp., Irvine, CA) and then used for reverse transcription with an iScript ${ }^{\mathrm{TM}}$ cDNA Synthesis Kit (Bio-Rad, Hercules, CA). Reaction mixtures were incubated for $5 \mathrm{~min}$ at $25^{\circ} \mathrm{C}, 30 \mathrm{~min}$ at $42{ }^{\circ} \mathrm{C}$, and $5 \mathrm{~min}$ at $85^{\circ} \mathrm{C}$. qRT-PCR was performed with a CFX96 Touch ${ }^{\text {TM }}$ Real-Time PCR Detection System using an iTaq ${ }^{\mathrm{TM}}$ Universal $\mathrm{SYBR}^{\circledR}$ Green Kit (Bio$\mathrm{Rad}$ ), with reaction for $3 \mathrm{~min}$ at $95{ }^{\circ} \mathrm{C}$ followed by 40 amplification cycles of $10 \mathrm{~s}$ at $95{ }^{\circ} \mathrm{C}$ and $1 \mathrm{~min}$ at $60{ }^{\circ} \mathrm{C}$. Primers for amplification were as follows: for $N R$, forward 5'-GCTGACAGCATCCTCATCAA-3' and reverse 5'GACAGAGTTGTCGGAGTTGTAG-3'; for GSIb, forward 5'-AGGACAGTGAAGTCATCCTCTA-3' and reverse 5'GTGTGTAGCAGTCGCACATA-3' . Perennial ryegrass elongation factor 1-alpha (forward 5' - GAGATGCACCACGAGTCTATG$3^{\prime}$ and reverse $5^{\prime}$-CCACATACCCACGCTTGATA-3') was used as a housekeeping gene for internal control. The transcript level of gene under each treatment was calculated as fold expression compared with housekeeping internal control. The analysis included three biological replicates (three pots) and three technical replicates for each treatment.

Data ANalysis. The experiment was a randomized complete block design three replicates (three blocks). Treatments were arranged randomly in each replicate regime. Statistical analysis was performed with SAS (version 9.1; SAS Institute, Cary, $\mathrm{NC}$ ). The means of the trait for the treatment were separated using least significant difference at a significance level of 0.05 .

\section{Results and Discussion}

Growth RESPONSES. The HT grown during the first $10 \mathrm{~d}$ of treatment increased 5.0, 4.5, 4.8,5.3,6.1, and $5.5 \mathrm{~cm}$ under 0 , $0.5,1.0,2.5,5.0$, and $7.5 \mathrm{~mm} \mathrm{~N}$, respectively, compared with plants before treatment (Fig. 1). Plants supplied with $0.5 \mathrm{~mm} \mathrm{~N}$ had the lowest HT, while plants supplied with $5.0 \mathrm{~mm} \mathrm{~N}$ had the highest HT. For the second cutting, larger variations in HT were observed among treatments, where HT grown during treatment increased $2.5,2.9,3.2,4.7,5.6$, and $5.6 \mathrm{~cm}$ under $0,0.5,1.0,2.5$, 5.0, and $7.5 \mathrm{~mm} \mathrm{~N}$, respectively, compared with plants before treatment (Fig. 1). The higher HT values were found under 2.5, 5.0 , and $7.5 \mathrm{~mm} \mathrm{~N}$, while a lower HT was observed under $0,0.5$, and $1.0 \mathrm{~mm} \mathrm{~N}$, particularly at 6 and $9 \mathrm{~d}$ after treatment. HT did not differ among $0,0.5$, and $1.0 \mathrm{~mm} \mathrm{~N}$ for the second cutting.

No differences in LFW were found among $0,0.5,1.0$, and $2.5 \mathrm{~mm} \mathrm{~N}$ for the first cutting, whereas plants treated with 5.0 and $7.5 \mathrm{~mm} \mathrm{~N}$ had $\approx 80 \%$ higher LFW than those supplied with $0,0.5$, or $1.0 \mathrm{~mm} \mathrm{~N}$ (Fig. 2). Similar responses of LDW were found under different $\mathrm{N}$ treatments. However, larger variations

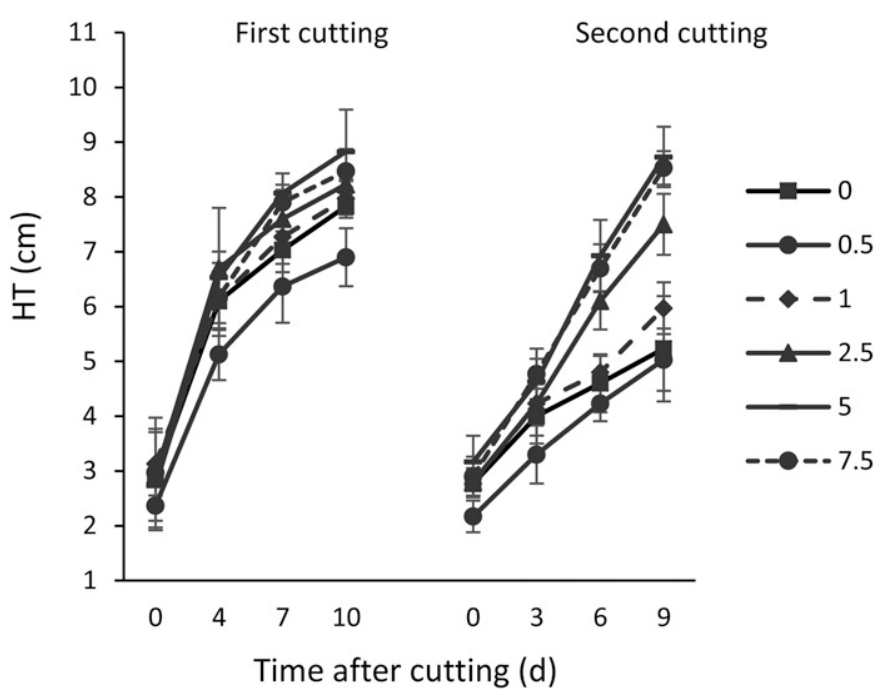

Fig. 1. Plant height (HT) as affected by 0-, 0.5-, 1.0-, 2.5-, 5.0-, and 7.5-mM nitrogen supply in perennial ryegrass accessions by one-way analysis of variance. Time after cutting indicate the number of days after plants were mowed and after the treatments were imposed. The first cutting took place at $10 \mathrm{~d}$ after treatment and the second cutting occurred at $20 \mathrm{~d}$ after treatment. Treatments are compared within each day of cutting using least significant difference. Means followed by the same letter within treatments for a given cutting are not significantly different at $P<0.05$. Bars indicate SD.

of both LFW and LDW were noted among treatments for the second cutting. Specifically, compared with non-N, LFW, and LDW did not change under the $0.5 \mathrm{~mm} \mathrm{~N}$ but significantly increased by $63.2 \%, 1.6-, 2.9-$, and 3.0 -fold under 1.0, 2.5, 5.0, and $7.5 \mathrm{~mm} \mathrm{~N}$, respectively. No differences in LFW and LDW were observed between the 5.0 and $7.5-\mathrm{mm} \mathrm{N}$ treatments for the second cutting. The results indicated that regrowth after cutting indicated by HT, LFW, and LDW were severely affected by N treatments.

Chlorophyll and Car contents were unaffected by $\mathrm{N}$ treatments for the first cutting, whereas differences in Chl and Car were found among $\mathrm{N}$ treatments for the second cutting (Fig. 2). Chlorophyll did not differ among 2.5, 5.0, and $7.5 \mathrm{~mm} \mathrm{~N}$, but plants grown under these three treatments maintained higher $\mathrm{Chl}$ than those receiving non-N or $0.5 \mathrm{~mm} \mathrm{~N}$. Compared with the non-N treatment, Chl significantly increased by $19.3 \%$, $19.7 \%, 24.6 \%, 11.7 \%$, and $9.5 \%$ under $0.5,1.0,2.5,5.0$, and $7.5 \mathrm{~mm}$ N, respectively. Unlike Chl, Car remained unchanged among all $\mathrm{N}$ treatments except for the non-N, with a lower Car observed in the leaves, compared with $2.5-, 5.0-, 7.5-\mathrm{mm} \mathrm{N}$ treatments.

In contrast to leaf growth, 0 and $0.5 \mathrm{~mm} \mathrm{~N}$ resulted in higher RFW than other four N treatments (Fig. 3). RFW was 3.8, 3.9, $3.2,3.1,3.2$, and $2.9 \mathrm{~g}$ for plants under $0,0.5,1.0,2.5,5.0$, and $7.5 \mathrm{~mm} \mathrm{~N}$, respectively. Treatments of $1.0,2.5,5.0$, and $7.5 \mathrm{~mm}$ $\mathrm{N}$ showed no differences in LFW. Similarly, higher RDW was noted under non- $\mathrm{N}$ and $0.5 \mathrm{~mm} \mathrm{~N}$, compared with 2.5-, 5.0-, and $7.5-\mathrm{mm} \mathrm{N}$ treatments. RDW was $0.62,0.55,0.54,0.45,0.45$, and $0.42 \mathrm{~g}$ for plants under $0,0.5,1.0,2.5,5.0$, and $7.5 \mathrm{~mm} \mathrm{~N}$, respectively. Root:leaf ratio generally decreased with increasing $\mathrm{N}$ supplies, with the highest value shown under non- $\mathrm{N}$ treatment, followed by 0.5 and $1.0 \mathrm{~mm} \mathrm{~N}$ (Fig. 3). This ratio was unchanged among the 2.5-, 5.0-, and 7.5-mm $\mathrm{N}$ treatments.

Nitrogen is a major component of the Chl molecule and largely determines leaf color and the health of a grass plant. 

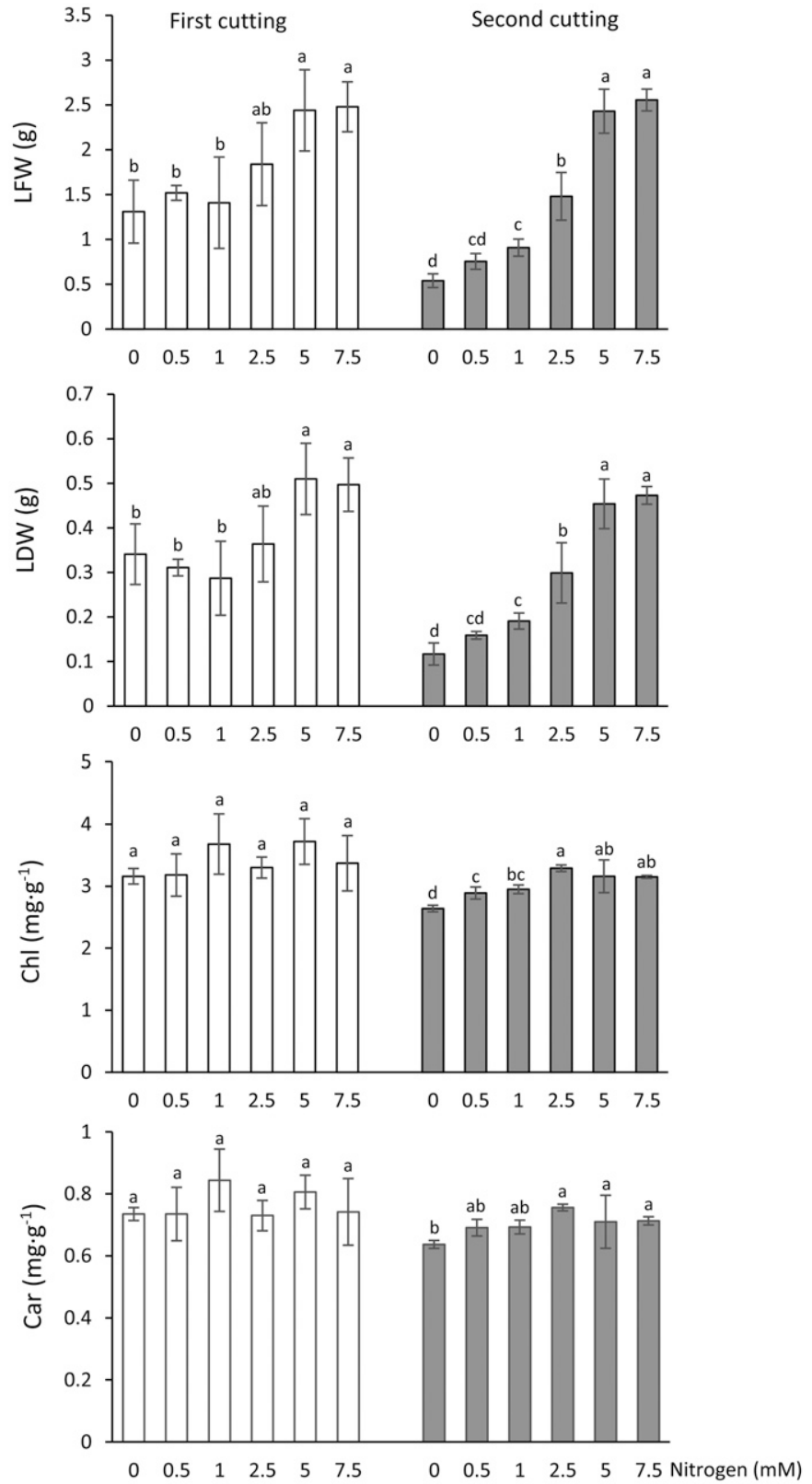

Fig. 2. Leaf fresh weight (LFW), dry weight (LDW), and chlorophyll (Chl) and carotenoid (Car) concentration as affected by $0-, 0.5-, 1.0-, 2.5-, 5.0-$, and 7.5-mm nitrogen supply in perennial ryegrass accessions by one-way analysis of variance. The first cutting takes place at $10 \mathrm{~d}$ after treatment and the second cutting occurs at $20 \mathrm{~d}$ after treatment. Treatments are compared within each cutting using least significant difference. Means followed by the same letter within treatments for a given cutting are not significantly different at $P<0.05$. Bars indicate SD.

However, Chl did not change under low N (e.g., 0 and $0.5 \mathrm{~mm} \mathrm{~N}$ ) until the second cutting, suggesting that $\mathrm{Chl}$ responded less rapidly and pronouncedly to low $\mathrm{N}$ than growth indicated by LDW (Fig. 1). It could be more related to lowering shoot density in grass plants under low $\mathrm{N}$ (Goron et al., 2015). Across 10 cool-season grass species in a controlled environment, plants responded to low $\mathrm{N}$ by decreasing shoot and root growth, but to a greater extent in shoots, resulting in an increase in root:shoot ratio (Skinner and Comas, 2010). Low N resulted in lower shoot dry weight, higher RDW, and higher root:shoot ratio of maize compared with the control, with increasing time of treatments
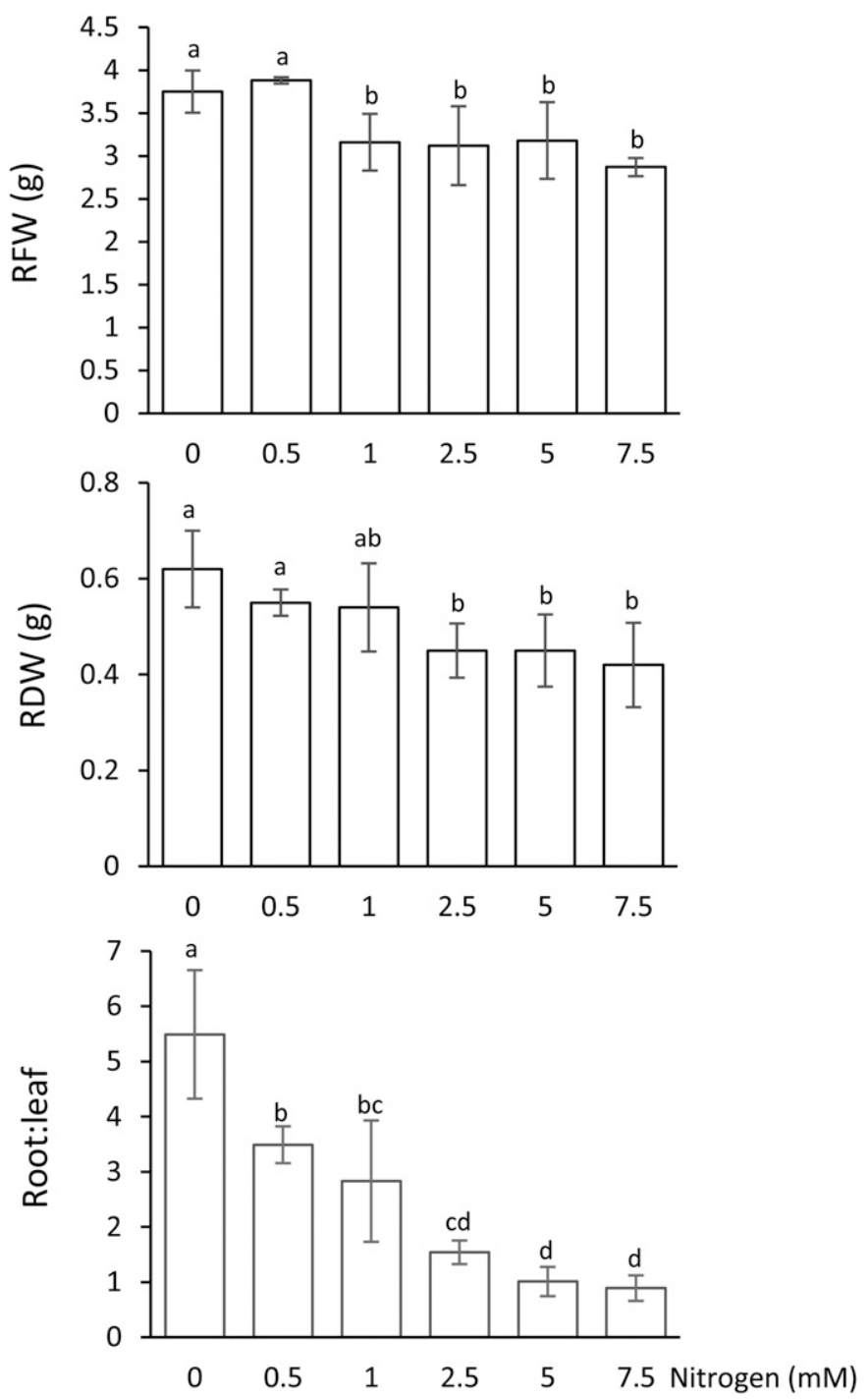

Fig. 3. Root fresh weight (RFW), dry weight (RDW), and root to leaf ratio (root: leaf) as affected by $0-, 0.5-, 1.0-, 2.5-, 5.0-$, and $7.5-\mathrm{mm}$ nitrogen supply in perennial ryegrass accessions by one-way analysis of variance. Measurements are made after the second cutting at $20 \mathrm{~d}$ after treatment. Treatments are compared within the second cutting using least significant difference. Means followed by the same letter within treatments for a given cutting are not significantly different at $P<0.05$. Bars indicate SD.

(Gao et al., 2015). Also in maize, 12 genotypes all had higher root:shoot ratio under the low-N treatment, indicating that shoot growth was more reduced than root growth (Sen et al., 2016). Our results in perennial ryegrass also demonstrated that non-N and low-N conditions had a significantly higher root:leaf ratio. Similar values of HT and LDW found between the 5.0 and $7.5 \mathrm{~mm} \mathrm{~N}$ suggested that perennial ryegrass growth was unaffected under optimal and suboptimal $\mathrm{N}$ conditions. Shoot and root dry growth in response to nitrogen supply can be mediated by cytokinins and sucrose (Van der Werf and Nagel, 1996). Under low-N condition, a small import of cytokinins occurs from roots to leaves, which results in a reduced photosynthetic capacity and rate of leaf expansion; so a relatively large fraction of sugars is available for roots, which enhances root growth (Van der Werf and Nagel, 1996). In addition, factors such as presence or absence of defoliation, 
species, cultivars, and experiment design can all cause variations of plant response to low N.

C AND $\mathbf{N}$ Content AND NUE. Leaf $\mathrm{N}$ content increased with increasing $\mathrm{N}$ supplies for the first cutting, ranging from $3.3 \%$ to $5.1 \%$ from non-N to $7.5 \mathrm{~mm} \mathrm{~N}$ (Fig. 4). Plants treated with $7.5 \mathrm{~mm} \mathrm{~N}$ had higher $\mathrm{N}$ content than all other treatments, but no differences in $\mathrm{N}$ content were observed between 2.5 and $5.0 \mathrm{~mm} \mathrm{~N}$ as well as between 0.5 and $1.0 \mathrm{~mm}$ $\mathrm{N}$. For the second cutting, treatments of 2.5, 5.0, and $7.5 \mathrm{~mm} \mathrm{~N}$ showed higher $\mathrm{N}$ content than that of $0,0.5$, and $1.0 \mathrm{~mm} \mathrm{~N}$, whereas leaf $\mathrm{N}$ content did not differ among these three treatments. The non- $\mathrm{N}$ treatments had the lowest $\mathrm{C}$ content $(42.5 \%)$ for the first cutting (Fig. 4). Unlike $\mathrm{N}$ content in leaves, there were no differences in $\mathrm{C}$ content from 1.0 - to $7.5-\mathrm{mm} \mathrm{N}$ treatments for the first cutting as well as among $0,0.5$, and $1.0 \mathrm{~mm}$ and among 2.5, 5.0, and $7.5 \mathrm{~mm} \mathrm{~N}$ for the second cutting, respectively. Also, the 2.5-mm $\mathrm{N}$ treatment exhibited the highest $\mathrm{C}$ content, which was $43.8 \%$ for the first cutting and $44.2 \%$ for the second cutting.

Leaf $\mathrm{C}: \mathrm{N}$ ratio decreased with increasing $\mathrm{N}$ supplies for the first cutting, ranging from $12.8 \%$ to $8.5 \%$ from non-N to $7.5 \mathrm{~mm} \mathrm{~N}$ (Fig. 4). For the second cutting, leaf $\mathrm{C}: \mathrm{N}$ ratio ranged from $14.0 \%$ for non-N treatment to $9.3 \%$ for $7.5 \mathrm{~mm} \mathrm{~N}$, but it was similar under 0 , 0.5 , and $1.0 \mathrm{~mm} \mathrm{~N}$. The 2.5-mM $\mathrm{N}$ treatment had a higher $\mathrm{C}: \mathrm{N}$ ratio than $7.5 \mathrm{~mm} \mathrm{~N}$. Similarly, LNUE decreased with increasing $\mathrm{N}$ supplies, ranging from $30.2 \%$ to $19.7 \%$ for the first cutting and $32.7 \%$ to $19.2 \%$ for the second cutting from non-N to $7.5 \mathrm{~mm} \mathrm{~N}$, respectively (Fig. 4). Plants supplied with 0 , 0.5 , and $1.0 \mathrm{~mm} \mathrm{~N}$ had higher LNUE than with $2.5,5.0$, and $7.5 \mathrm{~mm} \mathrm{~N}$, while there were no significant changes in LNUE among 0 , 0.5 , and $1.0 \mathrm{~mm}$ as well as among 2.5, 5.0, and $7.5 \mathrm{~mm} \mathrm{~N}$ for the second cutting.

For roots, $\mathrm{N}$ content significantly increased with increasing $\mathrm{N}$ supplies (Fig. 5). Specifically, N content was $0.80 \%, 0.88 \%$, $0.96 \%, 1.19 \%, 1.43 \%$, and $1.86 \%$ under 0 $0.5,1.0,2.5,5.0$, and $7.5 \mathrm{~mm} \mathrm{~N}$, respectively. However, no differences in root $\mathrm{C}$ content were found across treatments. The root $\mathrm{C}: \mathrm{N}$ ratio decreased with increasing $\mathrm{N}$ supplies and was $49.9 \%, 44.7 \%, 13.2 \%, 35.1 \%$, $27.6 \%$, and $22.2 \%$ under $0,0.5,1.0,2.5$, 5.0 , and $7.5 \mathrm{~mm} \mathrm{~N}$, respectively. Similar to the $\mathrm{C}: \mathrm{N}$ ratio, RNUE decreased with increasing $\mathrm{N}$ supplies across treatments and was $125.7,114.6,102.8,84.3,69.7$, and $54.0 \mathrm{~g} \cdot \mathrm{g}^{-1}$ under $0,0.5,1.0,2.5,5.0$, and $7.5 \mathrm{~mm} \mathrm{~N}$, respectively (Fig. 5).

Turf and forage grasses are subject to frequent defoliation by herbivores or
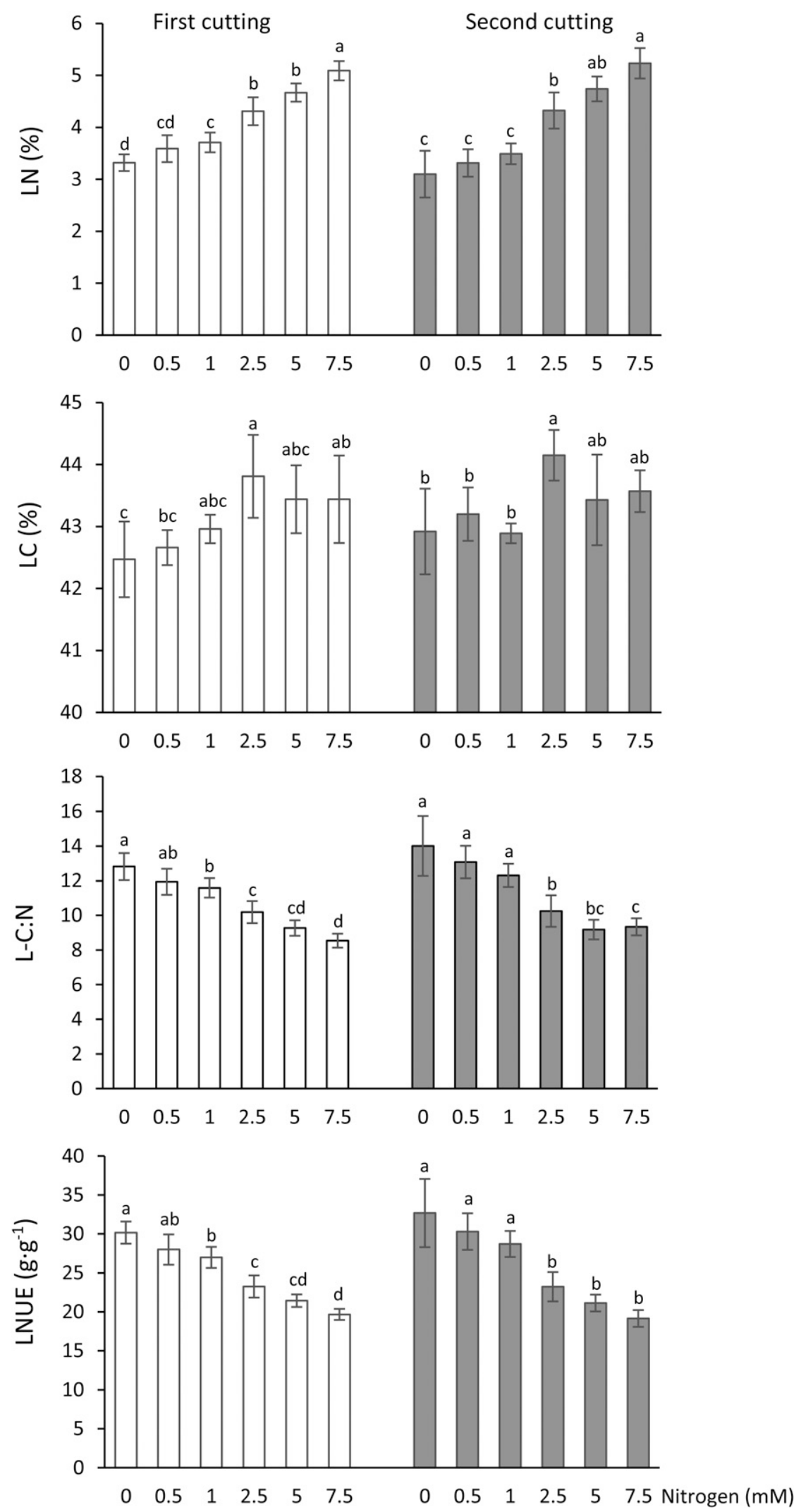

Fig. 4. Leaf nitrogen content (LN), leaf carbon content (LC), leaf carbon:nitrogen ratio (L-C:N), and leaf nitrogen use efficiency (LNUE) as affected by 0-, 0.5-, 1.0-, 2.5-, 5.0-, and 7.5-mm nitrogen supply in perennial ryegrass accessions by one-way analysis of variance. The first cutting takes place at $10 \mathrm{~d}$ after treatment and the second cutting occurs at $20 \mathrm{~d}$ after treatment. Treatments are compared within each cutting using least significant difference. Means followed by the same letter within treatments for a given cutting are not significantly different at $P<0.05$. Bars indicate SD. 
mechanical harvesting. Regrowth of grasses after cutting could be related to the availability of carbon and nitrogen reserves in the remaining tissues (Volenec et al., 1996). Our results
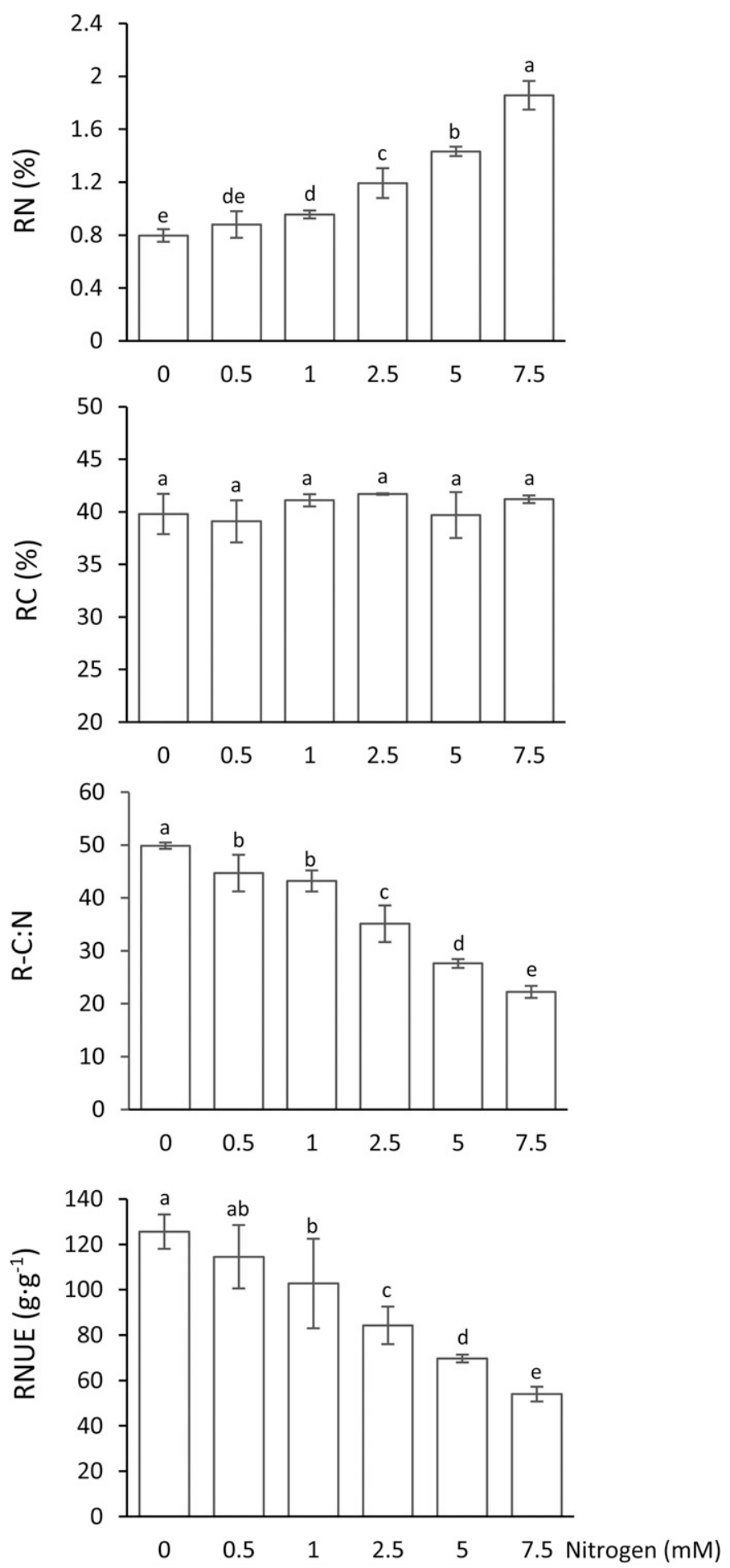

Fig. 5. Root nitrogen content $(\mathrm{RN})$, root carbon content $(\mathrm{RC})$, root carbon to nitrogen ratio (R-C:N), and root nitrogen use efficiency (RNUE) as affected by $0-, 0.5-, 1.0-, 2.5-, 5.0-$, and 7.5-mm nitrogen supply in perennial ryegrass accessions by one-way analysis of variance. Measurements are made after the second cutting at $20 \mathrm{~d}$ after treatment. Treatments are compared within the second cutting using least significant difference. Means followed by the same letter within treatments for a given cutting are not significantly different at $P<$ 0.05 . Bars indicate SD. supported this observation and demonstrated that decreasing $\mathrm{N}$ supply after the first cutting decreased the availability of $\mathrm{N}$ reserves in the leaves (the second cutting) and the absolute amount of $\mathrm{N}$ subsequently remobilized to the roots (Figs. 4 and 5). NUE is an important parameter indicating growth status in response to $\mathrm{N}$ availability in perennial turf species. NUE often decreases with increasing $\mathrm{N}$ applications in plant species (Campbell et al., 1993; Greef, 1994; Jiang and Hull, 1998). In this study, similar values of LNUE between 2.5 and $7.5 \mathrm{~mm} \mathrm{~N}$ for the second cutting suggested that high productivity, expressed as biomass in perennial grass, did not necessarily depend on high NUE when $\mathrm{N}$ supply was not too limiting. Efficiency of $\mathrm{N}$ use by perennial ryegrass may be associated with partitioning of $\mathrm{C}$ and $\mathrm{N}$ between roots and shoots, especially when defoliation occurred. For example, low-N treatments (0-1.0 mM) had similar leaf $\mathrm{N}$ and $C$, leaf $C: N$ ratio, $L N U E$, and $\operatorname{root} C$, but $\operatorname{root} N$, root $C: N$ ratio, and RNUE differed under these two treatments. The results indicated that cellular carbon and nitrogen metabolism might be tightly coordinated to sustain optimal growth and development for plants and other cellular organisms (Zheng, 2009). Such coordination can be altered by low, moderate, and high $\mathrm{N}$ supply.

GENe EXPRESSION. The treatment of $0.5 \mathrm{~mm} \mathrm{~N}$ showed significantly higher expression levels of leaf $N R$ than 2.5- and 7.5-mm $\mathrm{N}$ treatments, whereas no differences in gene expression of leaf $N R$ were found between 2.5 - and $7.5-\mathrm{mm} \mathrm{N}$ treatments for both cuttings (Fig. 6). Expression of leaf GS1b did not differ among three treatments for the first cutting but was significantly higher in $0.5 \mathrm{~mm} \mathrm{~N}$ than the other two treatments for the second cutting (Fig. 6). Expression of $N R$

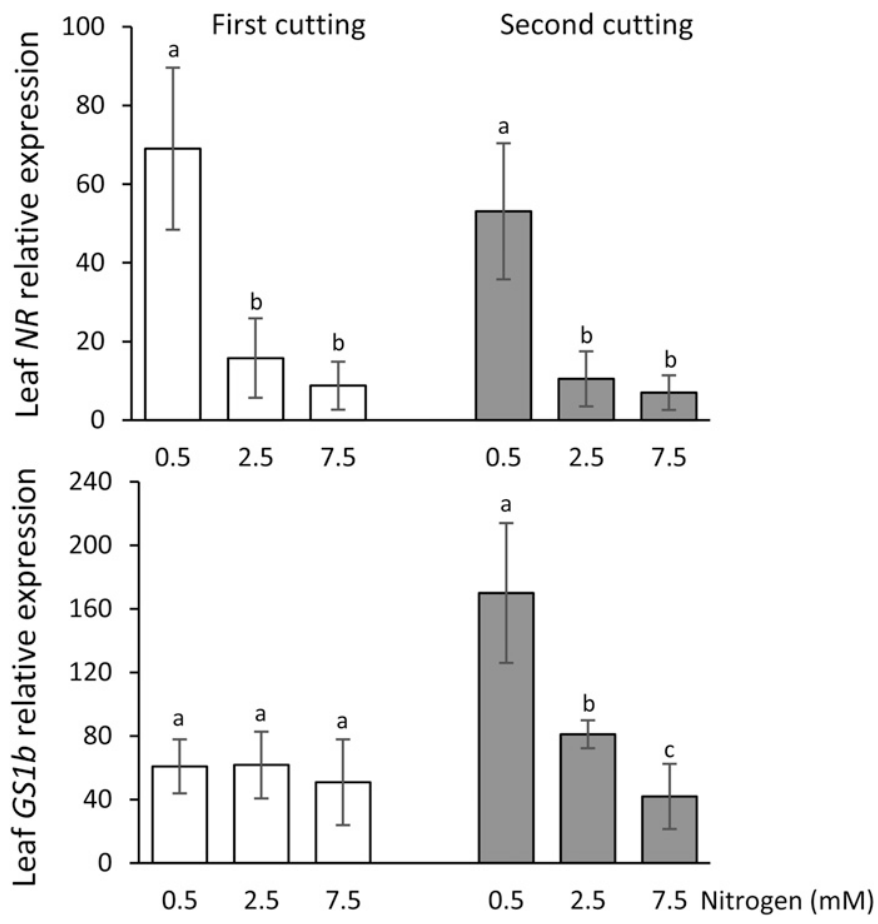

Fig. 6. Leaf transcript level of $N R$ encoding nitrogen reductase and $G S 1 b$ encoding glutamine synthetase as affected by $0.5-, 2.5-$, and 7.5-mM nitrogen supply in perennial ryegrass accessions by one-way analysis of variance. The first cutting takes place at $10 \mathrm{~d}$ after treatment and the second cutting occurs at $20 \mathrm{~d}$ after treatment. Treatments are compared within each cutting using least significant difference. Means followed by the same letter within treatments for a given cutting are not significantly different at $P<0.05$. Bars indicate SD. 


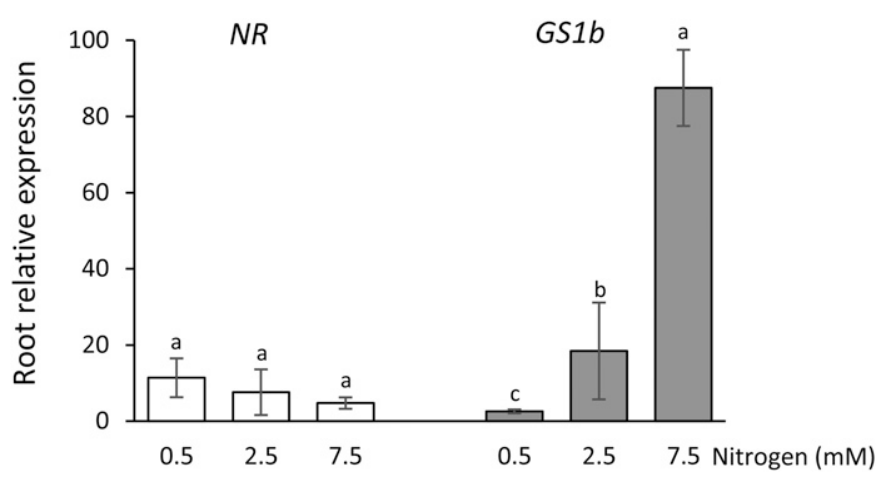

Fig. 7. Root transcript level of $N R$ encoding nitrogen reductase and $G S 1 b$ encoding glutamine synthetase as affected by $0.5-, 2.5-$, and 7.5-mM nitrogen supply in perennial ryegrass accessions by one-way analysis of variance. Measurements are made after the second cutting at $20 \mathrm{~d}$ after treatment. Treatments are compared within the second cutting using least significant difference. Means followed by the same letter within treatments for a given cutting are not significantly different at $P<0.05$. Bars indicate SD.

in roots did not alter among three treatments for the first cutting, while expressions of $G S 1 b$ were significantly higher under $7.5 \mathrm{~mm} \mathrm{~N}$ than other two treatments (Fig. 7).

Nitrate reductase is responsible for the primary assimilation of nitrate. Nitrate reduction occurs both in leaves and roots of perennial ryegrass. Nitrate reduction occurred primarily in the roots then shifts to the shoots in N-deficient grass (Bowman and Paul, 1988). Nitrogen form (nitrate, ammonium) did not affect partitioning of the absorbed $\mathrm{N}$ between roots and shoots but did affect growth (Bowman and Paul, 1988). Stronger expression of $N R$ in the leave under $0.5 \mathrm{~mm} \mathrm{~N}$ relative to high $\mathrm{N}$ condition in this study supported the finding of nitrate reduction described above. The results were also consistent with the research findings in barley (Xu et al., 2016) and wheat (Kavoosi et al., 2014). However, the levels of $N R$ transcript can be also low in nitrate-deficit plants (Scheible et al., 1997) and were repressed by $\mathrm{N}$ metabolites (Meyer and Stitt, 2001; Tsay et al., 2007).

Glutamine synthetase plays a major role in fixing ammonium to form the amino acid glutamine. Responses of $G S$ to nitrogen availability in both roots and leaves are not well understood. Under N deprivation, expression of GS1 gene can be up- or downregulated (Masclaux-Daubresse et al., 2005). We found stronger expression of $G S 1 b$ in the leaves of perennial ryegrass under lower $\mathrm{N}$, indicating an upregulation of these genes when $\mathrm{N}$ is low and a downregulation when $\mathrm{N}$ is high. The results were consistent with those found in barley (Xu et al., 2016) and wheat (Kavoosi et al., 2014). However, $G S 1 b$ was upregulated in the roots under high $\mathrm{N}$ condition (Fig. 7). The accumulation of cytosolic $G S$ gene transcripts declined in the nitrogen-repleted roots of oilseed rape (Brassica napus), leading to enhanced translocation of ammonium to the shoots (Finnemann and Schjoerring, 1999). In addition, transcript stability may regulate cytosolic $G S$ in response to nitrogen nutrition (Ortega et al., 2006). Therefore, higher expression of $G S 1 b$ in the roots in response to high $\mathrm{N}$ supply might be due to several reasons including ammonium concentration in the roots or transcript stability, which is not well understood and deserves a further investigation. The inconsistency in GS1 expression between studies is probably because of the complex regulation of GS. Collectively, expression of genes encoding NR and GS can vary with N availability, species, cultivars, and the experimental procedures.
In conclusion, moderate-to-high $\mathrm{N}$ supplies such as 2.5, 5.0, and $7.5 \mathrm{~mm} \mathrm{~N}$ resulted in higher leaf growth, $\mathrm{Chl}$, and leaf and root weight, lower $\mathrm{C}: \mathrm{N}$ ratio, and lower LNUE and RNUE. The non- $\mathrm{N}$ and low $\mathrm{N}(0.5$ and $1.0 \mathrm{~mm} \mathrm{~N})$ had lower $\mathrm{N}$ content, higher root growth, higher leaf and root $\mathrm{C}: \mathrm{N}$ ratio as well as higher LNUE and RNUE. Higher expression of $N R$ and GS1b in the leaves was found under low-N treatment but higher expression of $G S 1 b$ in the roots was observed under moderate-tohigh $\mathrm{N}$ treatment. Defoliation (cutting) dramatically altered the responses of the plants to various $\mathrm{N}$ supplies. Perennial ryegrass supplied with moderate concentrations of $\mathrm{N}$ (e.g., 2.5 to $5 \mathrm{~mm}$ ) could be better balancing of N, C, NUE, and growth, especially after cutting. A range of 0.5 to $1 \mathrm{~mm} \mathrm{~N}$ seemed adequate for phenotyping responses of a large population of perennial ryegrass to low-N conditions.

\section{Literature Cited}

Arrobas, M., M.J. Parada, P. Magalhães, and M.A. Rodrigues. 2011. Nitrogen-use efficiency and economic efficiency of slow-release $\mathrm{N}$ fertilisers applied to irrigated turfs in a Mediterranean environment. Nutr. Cycl. Agroecosyst. 89:329-339.

Bao, A., Z. Zhao, G. Ding, L. Shi, F. Xu, and H. Cai. 2014. Accumulated expression level of cytosolic glutamine synthetase 1 gene $(O s G S 1 ; 1$ or $O s G S 1 ; 2)$ alter plant development and the carbonnitrogen metabolic status in rice. PLoS One 9:e95581.

Bowman, D.C. and J.L. Paul. 1998. Uptake and assimilation of $\mathrm{NO}_{3}$ and $\mathrm{NH}_{4}{ }^{+}$by nitrogen-deficient perennial ryegrass turf. Plant Physiol. 88:1303-1309.

Brauer, E.K., A. Rochon, Y.M. Bi, G.G. Bozzo, S.J. Rothstein, and B.J. Shelp. 2011. Reappraisal of nitrogen use efficiency in rice overexpressing glutamine synthetase. Physiol. Plant. 141:361-372.

Bushoven, J.T. and R.J. Hull. 2001. Nitrogen use efficiency is linked to nitrate reductase activity and biomass partitioning between roots and shoots of perennial ryegrass and creeping bentgrass. Intl. Turfgrass Soc. Res. J. 9:245-252.

Campbell, C.A., R.P. Zentner, F. Selles, B.G. McConkey, and F.B. Dyck. 1993. Nitrogen management for spring wheat grown annually on zero-tillage: Yields and nitrogen use efficiency. Agron. J. 85:107-114.

Finnemann, J. and J.K. Schjoerring. 1999. Translocation of $\mathrm{NH}_{4}{ }^{+}$in oilseed rape plants in relation to glutamine synthetase isogene expression and activity. Physiol. Plant. 105:469-477.

Foito, A., S.L. Byrne, C.A. Hackett, R.D. Hancock, D. Stewart, and S. Barth. 2013. Short-term response in leaf metabolism of perennial ryegrass (Lolium perenne) to alterations in nitrogen supply. Metabolomics 9:145-156.

Gao, K., F. Chen, L. Yuan, F. Zhang, and G. Mi. 2015. A comprehensive analysis of root morphological changes and nitrogen allocation in maize in response to low nitrogen stress. Plant Cell Environ. 28:740-750.

Good, A.G., A.K. Shrawat, and D.G. Muench. 2004. Can less yield more? Is reducing nutrient input into the environment compatible with maintaining crop production? Trends Plant Sci. 9:597-605.

Goron, T.L., V.K. Bhosekar, C.R. Shearer, S. Watts, and M.N. Raizada. 2015. Whole plant acclimation responses by finger millet to low nitrogen stress. Front. Plant Sci. 6:652.

Greef, J.M. 1994. Productivity of maize (Zea mays L.) in relation to morphological and physiological characteristics under varying amounts of nitrogen supply. J. Agron. Crop Sci. 172:317-326.

Haynes, R.J. and P.H. Williams. 1993. Nutrient cycling and soil fertility in the grazed pasture ecosystem. Adv. Agron. 49:119-199.

Hirel, B. and P. Lea. 2001. Ammonia assimilation, p. 79-100. In: P.J. Lea and J.F. Morot-Gaudry (eds.). Plant nitrogen. Springer-Verlag, Berlin, Germany.

Hoagland, D.R. and D.I. Arnon. 1950. The water-culture method for growing plants without soil. California Agr. Expt. Sta. Circ. 347. 
Jiang, Z. and R.J. Hull. 1998. Interrelationships of nitrate uptake, nitrate reductase, and nitrogen use efficiency in selected kentucky bluegrass cultivars. Crop Sci. 38:1623-1632.

Jiang, Z., W.M. Sullivan, and R.J. Hull. 2000. Nitrate uptake and nitrogen use efficiency by kentucky bluegrass cultivars. HortScience 35:1350-1354.

Jiang, Z., C. Xu, and B. Huang. 2011. Enzymatic metabolism of nitrogen in leaves and roots of creeping bentgrass under nitrogen deficiency conditions. J. Amer. Soc. Hort. Sci. 136:320-328.

Kavoosi, G., S. Balotf, H. Eshghi, and H. Hasani. 2014. Analysis of nitrate reductase mRNA expression and nitrate reductase activity in response to nitrogen supply. Mol. Biol. Res. Comm. 3:75-84.

Liu, H. and R.J. Hull. 2006. Comparing cultivars of three coolseason turfgrasses for nitrogen recovery in clippings. HortScience 41:827-831.

Masclaux-Daubresse, C., E. Carrayol, and M.-H. Valadier. 2005. The two nitrogen mobilisation- and senescence-associated GS1 and GDH genes are controlled by $\mathrm{C}$ and $\mathrm{N}$ metabolites. Planta 221:580-588.

Masclaux-Daubresse, C., F. Daniel-Vedele, J. Dechorgnat, F. Chardon, L. Gaufichon, and A. Suzuki. 2010. Nitrogen uptake, assimilation and remobilization in plants: Challenges for sustainable and productive agriculture. Ann. Bot. (Lond.) 105:1141-1157.

Mattsson, M. and J.K. Schjoerring. 2002. Dynamic and steady-state responses of inorganic nitrogen pools and $\mathrm{NH} 3$ exchange in leaves of Lolium perenne and Bromus erectus to changes in root nitrogen supply. Plant Physiol. 128:742-750.

Meyer, C. and M. Stitt. 2001. Nitrate reduction and signaling, p. 61-78. In: P.J. Lea and J.F. Morot-Gaudry (eds.). Plant nitrogen 2. SpringerVerlag, Berlin, Germany.

Moir, J.L., G.R. Edwards, and L.N. Berry. 2012. Nitrogen uptake and leaching loss of thirteen temperate grass species under high $\mathrm{N}$ loading. Grass Forage Sci. 68:313-325.

Ortega, J.L., S. Moguel-Esponda, C. Potenza, C.F. Conklin, A. Quintana, and C. Sengupta-Gopalan. 2006. The 3' untranslated region of a soybean cytosolic glutamine synthetase (GS1) affects transcript stability and protein accumulation in transgenic alfalfa. Plant J. 45:832-846.

Poudel, B., D. Rowland, J. Erickson, B. Unruh, and K. Kenworthy. 2013. Nitrogen partitioning comparisons among warm-season turfgrass species. Intl. Turfgrass Soc. Res. J. 12:503-507.

Rasmussen, S., A.J. Parsons, K. Fraser, H. Xue, and J.A. Newman. 2008. Metabolic profiles of Lolium perenne are differentially affected by nitrogen supply, carbohydrate content, and fungal endophyte infection. Plant Physiol. 146:1440-1453.

Roche, J., J. Love, Q. Guo, J. Song, M. Cao, K. Fraser, J. Huege, C. Jones, O. Novák, M.H. Turnbull, and P.E. Jameson. 2016. Metabolic changes and associated cytokinin signals in response to nitrate assimilation in roots and shoots of Lolium perenne. Physiol. Plant. 156:497-511.

Scheible, W.R., A. González-Fontes, R. Morcuende, M. Lauerer, M. Geiger, J. Glaab, A. Gojon, E.D. Schulze, and M. Stitt. 1997. Tobacco mutants with a decreased number of functional NIA genes compensate by modifying the diurnal regulation of transcription, post-translational modification and turnover of nitrate reductase. Planta 203:304-319.

Sen, S., M.E. Smith, and T. Setter. 2016. Effects of low nitrogen on chlorophyll content and dry matter accumulation in maize. Afr. J. Agr. Res. 11:1001-1007.

Sinclair, T.R. and V. Vadez. 2002. Physiological traits for crop yield improvement in low N and P environments. Plant Soil 245:1-15.

Skinner, H. and L.H. Comas. 2010. Root distribution of temperate forage species subjected to water and nitrogen stress. Crop Sci. 50:2178-2185.

Tsay, Y.F., C.C. Chiu, C.B. Tsai, C.H. Ho, and P.K. Hsu. 2007. Nitrate transporters and peptide transporters. FEBS Lett. 581:2290-2300.

Van der Werf, A. and O.W. Nagel. 1996. Carbon allocation to shoots and roots in relation to nitrogen supply is mediated by cytokinins and sucrose. Plant Soil 185:21-32.

Volenec, J.J., A. Ourry, and B.C. Joern. 1996. A role for nitrogen reserves in forage regrowth and stress tolerance. Physiol. Plant. 97:185-193.

Wellburn, A.R. 1994. The spectral determination of chlorophylls a and b, as well as total carotenoids, using various solvents with spectrophotometers of different resolution. J. Plant Physiol. 144:307-313.

Xu, H., C. Liu, R. Lu, G. Guo, Z. Chen, T. He, R. Gao, Y. Li, and J. Huang. 2016. The difference in responses to nitrogen deprivation and re-supply at seedling stage between two barley genotypes differing nitrogen use efficiency. Plant Growth Regulat. 79:119-126.

Zhao, X.-Q., X.-L. Nie, and X.-G. Xiao. 2013. Over-expression of a tobacco nitrate reductase gene in wheat (Triticum aestivum L.) increases seed protein content and weight without augmenting nitrogen supplying. PLoS One 8:e74678.

Zheng, Z.L. 2009. Carbon and nitrogen nutrient balance signaling in plants. Plant Signal. Behav. 4:584-591. 